\title{
THE CONSTRAINTS ANALYSIS OF IMPLEMENTING SCHOOL LITERACY MOVEMENT AT SDN 2 KALIBENING
}

\author{
Nashri Maulidah, Neni Dewi Anggraeni, Tria Mugi Safitri, Siti Fatimah
}

Universitas Sebelas Maret

nashrimaulidah57@gmail.com

\begin{tabular}{l} 
Article History \\
\hline accepted 30/09/2018 \\
approved 12/10/2018 \\
published 30/10/2018
\end{tabular}

Keywords

school literacy movement, reading and writing

interest, elementary school

\begin{abstract}
School literacy movement is one of the efforts to increase students' interest in reading and writing, so it needs to be applied in elementary school. This study aims to analyze the constraints with regard to implementation of the school literacy movement at SDN 2 Kalibening, Karanggayam, Kebumen. This research is a descriptive study with research subjects involving 1 principal, 3 classroom teachers (grade 4, 5 and 6) and 15 students (grades 4, 5 and 6) state elementary school 2 of Kalibening. The research instruments used were questionnaires and interviews. Data analysis technique uses qualitative descriptive. The results showed that: (1) School literacy movement was still focused on literacy aspects of reading textbooks, (2) Teachers were less maximal in assisting students when implementing school literacy movements, and (3) The lack of facility to support the school literacy movement.
\end{abstract}

p-ISSN 2620-9284 e-ISSN 2620-9292

Social, Humanities, and Education Studies (SHEs): Conference Series https://jurnal.uns.ac.id/shes 


\section{PENDAHULUAN}

Salah satu faktor penting dalam kemajuan suatu bangsa adalah sumber daya manusia yang berkualitas tinggi. Kriteria ini akan didapat jika terdapat program yang mendukung dalam bidang pendidikan sebagai tolak ukur sumber daya manusia yang berkualitas tersebut. Salah satu upayanya yaitu dengan peningkatan di bidang literasi.

Literasi adalah kemampuan mengakses, memahami, dan menggunakan sesuatu secara cerdas melalui berbagai aktivitas, antara lain membaca, melihat, menyimak, menulis, dan/atau berbicara (Kemdikbud, 2016). Secara sederhana literasi diartikan sebagai kegiatan membaca dan menulis.

Untuk mendukung literasi tersebut maka diperlukan sebuah program gerakan literasi sekolah. Faizah (2016) menyatakan bahwa Gerakan Literasi Sekolah merupakan sebuah upaya yang dilakukan secara menyeluruh untuk menjadikan sekolah sebagai organisasi pembelajaran yang warganya literat sepanjang hayat melalui pelibatan publik. Warga yang literat adalah warga yang sadar akan pentingnya aktivitas literasi. Aktivitas literasi tidak terbatas pada kegiatan membaca dan menulis saja, tetapi juga mencakup keberpahamannya pada bidang-bidang tertentu, mampu memilah informasi dengan baik dan berkomunikasi berdasarkan fakta yang ada.

(Ferguson, 2003) menyatakan bahwa komponen literasi informasi terdiri atas literasi dini, literasi dasar, literasi perpustakaan, literasi media, literasi teknologi, dan literasi visual. Komponen literasi tersebut dijelaskan sebagai berikut:

1. Literasi Dini (Early Literacy) yaitu kemampuan untuk menyimak, memahami bahasa lisan, dan berkomunikasi melalui gambar dan lisan yang dibentuk oleh pengalamannya berinteraksi dengan lingkungan sosialnya di rumah. Pengalaman peserta didik dalam berkomunikasi dengan bahasa ibu menjadi fondasi perkembangan literasi dasar.

2. Literasi Dasar (Basic Literacy) yaitu kemampuan untuk mendengarkan, berbicara, membaca, menulis, dan menghitung (counting) berkaitan dengan kemampuan analisis untuk memperhitungkan (calculating), mempersepsikan informasi (perceiving), mengomunikasikan, serta menggambarkan informasi berdasarkan pemahaman dan pengambilan kesimpulan pribadi.

3. Literasi Perpustakaan (Library Literacy) antara lain, memberikan pemahaman cara membedakan bacaan fiksi dan nonfiksi, memanfaatkan koleksi referensi dan periodikal, memahami Dewey Decimal System sebagai klasifikasi pengetahuan yang memudahkan dalam menggunakan perpustakaan, memahami penggunaan katalog dan pengindeksan, hingga memiliki pengetahuan dalam memahami informasi ketika sedang menyelesaikan sebuah tulisan, penelitian, pekerjaan, atau mengatasi masalah.

4. Literasi Media (Media Literacy) yaitu kemampuan untuk mengetahui berbagai bentuk media yang berbeda, seperti media cetak, media elektronik (media radio, media televisi), media digital (media internet), dan memahami tujuan penggunaannya.

5. Literasi Teknologi (Technology Literacy) yaitu kemampuan memahami kelengkapan yang mengikuti teknologi seperti peranti keras (hardware), peranti lunak (software), serta etika dan etiket dalam memanfaatkan teknologi. Berikutnya, kemampuan dalam memahami teknologi untuk mencetak, mempresentasikan, dan mengakses internet. Dalam praktiknya, juga pemahaman menggunakan computer (Computer Literacy) yang di dalamnya mencakup menghidupkan dan mematikan komputer, menyimpan dan mengelola data, serta mengoperasikan program perangkat lunak. Sejalan dengan membanjirnya informasi karena perkembangan teknologi saat ini, diperlukan pemahaman yang baik dalam mengelola informasi yang dibutuhkan masyarakat. 
6. Literasi Visual (Visual Literacy) adalah pemahaman tingkat lanjut antara literasi media dan literasi teknologi, yang mengembangkan kemampuan dan kebutuhan belajar dengan memanfaatkan materi visual dan audiovisual secara kritis dan bermartabat. Tafsir terhadap materi visual yang tidak terbendung, baik dalam bentuk cetak, auditori, maupun digital (perpaduan ketiganya disebut teks multimodal), perlu dikelola dengan baik. Bagaimanapun di dalamnya banyak manipulasi dan hiburan yang benarbenar perlu disaring berdasarkan etika dan kepatutan.

Indonesia sebagai negara dengan jumlah penduduk terbesar ke empat nyatanya masih belum mampu memaksimalkan kualitas sumber daya manusia yang dimiliki, hal ini ditemui dari beberapa fakta bahwa gerakan literasi masih terhitung rendah. Penelitian yang dilakukan PISA 2015 yang menunjukkan tingkat membaca siswa masih stagnan, yaitu dari poin 396 di tahun 2012 menjadi 397 di tahun 2015 (Kemdikbud, 2016).

Minat membaca adalah kemauan dari setiap orang untuk melakukan kegiatan membaca dalam aktivitasnya. Witanto (2018) menyatakan bahwa sedikitnya terdapat 3 faktor rendahnya minat baca yaitu:

1. Belum ada kebiasaan membaca yang ditanamkan sejak dini.

2. Akses ke fasilitas pendidikan belum merata dan minimnya kualitas sarana pendidikan.

3. Kurangnya produksi buku di Indonesia sebagai dampak dari belum berkembangnya penerbit di daerah, insentif bagi produsen buku dirasa belum adil, dan wajib pajak bagi penulis yang mendapatkan royalti rendah sehingga memadamkan motivasi mereka untuk melahirkan buku berkualitas.

Selain itu Triatma dkk (2016) menyatakan rendahnya minat membaca anak sekolah dasar disebabkan oleh beberapa hal diantaranya mahalnya harga buku dan terbatasnya fasilitas perpustakaan yang menyebabkan membaca tidak lagi sebagai sarana pembelajaran dan hiburan bagi masyarakat Indonesia. Masyarakat Indonesia lebih memilih membeli televisi dibanding membeli buku.

Oleh karena itu, untuk meningkatkan kemampuan literasi bangsa Indonesia, maka diadakan gerakan literasi sekolah. Gerakan ini digagas oleh Kementerian Pendidikan dan Kebudayaan melalui Peraturan Menteri nomor 23 tahun 2013 dengan meluncurkan sebuah gerakan literasi sekolah di setiap jenjang pendidikan.

Salah satu jenjang pendidikan penting untuk membudayakan gerakan literasi sekolah adalah pada jenjang sekolah dasar. Dimana pada jenjang ini rasa ingin tahu anak tinggi sehingga sangat tepat untuk diarahkan pada budaya literasi khususnya minat membaca anak.

Mulyono (2017) menyatakan bahwa pelaksanaan gerakan literasi di sekolah dasar terbagi menjadi 3 tahap yaitu :

1. Tahap ke-1: Pembiasaan kegiatan membaca yang menyenangkan di ekosistem sekolah. Pembiasaan ini bertujuan untuk menumbuhkan minat terhadap bacaan dan terhadap kegiatan membaca dalam diri warga sekolah. Penumbuhan minat baca merupakan hal fundamental bagi pengembangan kemampuan literasi peserta didik.

2. Tahap ke-2: Pengembangan minat baca untuk meningkatkan kemampuan literasi. Kegiatan literasi pada tahap ini bertujuan mengembangkan kemampuan memahami bacaan dan mengaitkannya dengan pengalaman pribadi, berpikir kritis, dan mengolah kemampuan komunikasi secara kreatif melalui kegiatan menanggapi bacaan pengayaan.

3. Tahap ke-3: Pelaksanaan pembelajaran berbasis literasi. Kegiatan literasi pada tahap pembelajaran bertujuan mengembangkan kemampuan memahami teks dan mengaitkannya dengan pengalaman pribadi, berpikir kritis, dan mengolah 
kemampuan komunikasi secara kreatif melalui kegiatan menanggapi teks buku bacaan pengayaan dan buku pelajaran.

Dari berbagai fakta-fakta tersebut kami tertarik untuk menganalisis kendalakendala SDN 2 Kalibening sebagai salah satu sekolah yang sudah menerapkan gerakan literasi sekolah. Hal ini dikarenakan masih jarangnya sekolah dasar di daerah terpencil yang menerapkan gerakan literasi sekolah. Dan perkembangannya SDN 2 Kalibening sudah masuk ke dalam tahap pembiasaan. Tujuannya untuk lebih memahami keterlaksanaan gerakan literasi pada satuan pendidikan dasar.

\section{METODE}

Penelitian ini merupakan penelitian deskriptif yang dilakukan untuk memperoleh gambaran mengenai pelaksanaan program gerakan literasi sekolah di SDN 2 Kalibening yang masih terdapat kendala dalam proses pelaksaaannya. Instrumen penelitian ini terdiri dari lembar angket dan wawancara yang diadopsi dari buku pedoman gerakan literasi sekolah di sekolah dasar. Subjek penelitian adalah satu orang kepala sekolah, tiga orang guru (kelas 4, 5, dan 6), dan 15 peserta didik. Teknik analisis data menggunakan analisis deskriptif kualitatif.

Untuk mencari besar presentase keberhasilan gerakan literasi sekolah menggunakan persamaan berikut

$$
\text { Presentase Keberhasilan }(p)=\frac{\text { Skoryang didapatkan }}{\text { Skor Maksimal }} \times 100 \%
$$

\section{HASIL DAN PEMBAHASAN \\ Pelaksanaan Program Gerakan Literasi Sekolah}

Berdasarkan hasil wawancara diperoleh informasi bahwa Sekolah Dasar Negeri 2 Kalibening telah melaksanakan program gerakan literasi sekolah sejak tahun 2017 yang diinisiasi oleh mahasiswa KKN IAINU Kebumen. Pelaksanaan program GLS di SDN 2 Kalibening sudah dalam tahap pembiasaan dimana dalam tahapan tersebut bertujuan untuk menumbuhkan minat peserta didik terhadap bacaan dan terhadap kegiatan membaca. Kegiatan pembiasaan literasi di SDN 2 Kalibening berisi kegiatan membaca oleh siswa selama 15 menit sebelum pembelajaran dimulai. Guru di SDN 2 Kalibening ikut mendampingi proses GLS sedangkan peran dari kepala sekolah di SD tersebut yaitu mendampingi dan memantau terlaksananya gerakan literasi sekolah. Dari hasil penelitian melalui angket yang diberikan kepada kepala sekolah, guru dan siswa diperoleh data yang menyatakan bahwa tingkat keberhasilan pelaksanaan gerakan literasi sekolah mencapai $63,7 \%$. Dengan demikian pelaksanaan gerakan literasi sekolah di SDN 2 Kalibening sudah baik. Namun terdapat beberapa kendala dalam pelaksanaannya sehingga kegiatan gerakan literasi sekolah di sekolah dasar tersebut belum berjalan secara optimal.

\section{Gerakan literasi sekolah masih terfokus pada aspek literasi membaca buku pelajaran}

Seperti yang diketahui bahwa gerakan literasi memiliki berbagai komponen dari literasi dini sampai pada literasi visual. Pada pelaksanaan GLS di SDN 2 Kalibening masih memfokuskan kegiatan literasi pada kegiatan membaca saja sehingga kegiatan tersebut hanya terfokus pada kegiatan membaca. Padahal dalam literasi dasar terdapat aspek berbicara, menulis dan menghitung yang semua aspek itu harus ikut dikembangkan. Selain itu berdasarkan penuturan sejumlah siswa sekolah dasar kelas 4, 5 dan 6, menyatakan bahwa dalam kegiatan literasi, mereka diarahkan oleh guru untuk membaca buku pelajaran saja. Sedangkan berdasarkan Buku Panduan Gerakan 
Literasi Sekolah di Sekolah Dasar yang diterbitkan oleh kemendikbud tahun 2016 dijelaskan bahwa dalam pelaksanaan GLS, buku yang dibaca atau dibacakan adalah buku bacaan yang disukai oleh siswa, bukan buku teks pelajaran. Sehingga dengan terfokusnya pembiasaan literasi pada kegiatan membaca buku pelajaran menyebabkan ketertarikan siswa terhadap minat baca menjadi menurun dan wawasan mereka mengenai jenis bacaan selain buku pelajaran menjadi sangat minim.

\section{Guru kurang maksimal dalam mendampingi siswa untuk melaksanakan gerakan literasi sekolah.}

Siswa sekolah dasar saat ini masih asing dengan gerakan literasi, mereka hanya tahu kegiatan pembiasaan di sekolah yaitu membaca dan menulis. Dalam gerakan literasi sekolah guru dan siswa membaca bersama atau guru membacakan untuk siswa. Namun di SDN 2 Kalibening guru hanya menyuruh siswanya untuk membaca tanpa ada pendampingan. Hal tersebut mengakibatkan siswa yang tidak tahu bahwa dalam pembiasaan gerakan literasi sekolah yang dibaca merupakan buku non pelajaran, malah siswa tersebuat hanya membaca buku pelajaran yang mereka bawa. Saat wawancara pun siswa tidak bisa menjawab jenis-jenis buku, seperti buku dongeng, fabel, cerita rakyat, dan lain-lain. Yang mereka tahu hanya buku pelajaran yang mereka miliki. Adapun siswa yang memang suka membaca dan aktif datang ke perpustakaan untuk membaca buku non pelajaran yang mereka sukai, namun sangat sedikit. Padahal mereka adalah siswa kelas tinggi yang seharusnya sudah bisa memilih secara mandiri buku yang akan mereka baca.

\section{Minimnya sarana dalam mendukung gerakan literasi sekolah.}

Untuk pelaksanaan suatu kegiatan harus adanya sarana yang memadai. Seperti halnya penerapan gerakan literasi sekolah perlu adnya sarana untuk menunjang pelaksanaan kegiatan. Sarana yang dibutuhkan yaitu sudut baca kelas, perpustakan, dan area baca. Untuk menumbuhkan minat baca, sarana tersebut dapat diperkaya dengan bahan kaya teks. Dalam kenyataan di SDN 2 Kalibening sangat kurang dalam sarana untuk penerapan gerakan literasi sekolah. Bangunan perpustakaan di SDN 2 Kalibening yang berdiri tahun 2010 harus digusur karena ada pelebaran jalan di depan Sekolah, sehingga salah satu ruang kelas dialih fungsikan sebagai ruang perpustakaan yang tidak terlalu luas. Dengan ruang perpustakaan yang sempit dan terdapat papan tenis meja di dalamnya akan mengganggu pengunjung perputakaan serta tidak nyaman, namun buku-buku di dalamnya sudah lengkap. Selain itu di sekolah tersebut juga sangat minim area baca dikarenakan tidak adanya kantin dan UKS yang bisa menjadi sarana dalam gerakan literasi sekolah, hanya ada satu kalimat motivasi yang ada di luar kelas dan hanya beberapa kelas yang di dalamnya terdapat bahan kaya bacaan. Untuk sudut baca kelas di SDN 2 Kalibening sudah ada di setiap kelas, namun hanya ada buku pelajaran yang tersedia. Padahal dalam kegiatan pembiasaan gerakan literasi sekolah seharusnya buku non pelajaran yang dibaca, karena buku pelajaran pasti setiap siswa akan membacanya untuk kegiatan pembelajaran.

\section{SIMPULAN}

Hasil penelitian menunjukan bahwa : (1) Gerakan literasi sekolah masih terfokus pada aspek literasi membaca buku pelajaran, (2) Guru kurang maksimal dalam mendampingi siswa saat pelaksanaan gerakan literasi sekolah, dan (3) Minimnya sarana dalam mendukung gerakan literasi sekolah.

\section{DAFTAR PUSTAKA}

Faizah, D. U., dkk. (2015). Panduan Gerakan Literasi Sekolah di Sekolah Dasar. Jakarta: Direktorat Jenderal Pendidikan Dasar dan Menengah Kementerian Pendidikan dan Kebudayaan. 
Ferguson, B. (2003). Information Literacy: A Primer for Teachers, Librarians, and other Informed People. Diakses dari https://binliotech.us/pdfs/InfoLit.pdf pada tanggal 11 Oktober 2018.

Teguh, M. (2017). Gerakan Literasi Sekolah Dasar. Prosiding Seminar Nasional 15 Maret 2017. Diakses dari http://eprints.umk.ac.id/7379/6/3 Mulyo Teguh.pdf pada tanggal 12 Oktober 2018.

Triatma, I. N. (2016). Minat Baca Pada Siswa Kelas Vi Sekolah Dasar Negeri Delegan 2 Prambanan Sleman Yogyakarta. E-Jurnal Prodi Teknologi Pendidikan Vol. V $\begin{array}{lllll}\text { Nomor } & 6 & \text { Tahun } & 2016 . & \text { Diakses }\end{array}$ http://journal.student.uny.ac.id/ojs/index.php/fiptp/article/view/3098/2794 pada tanggal 12 Oktober 2018.

Witanto, J. (2018). Rendahnya Minat Baca. Diakses dari https://www.researchgate.net/publication/324182095 Rendahnya Minat Baca pada tanggal 12 Oktober 2018. 